Металлофиз. новейшие технол. / Metallofiz. Noveishie Tekhnol. () 2015 ИМФ (Институт металлофизики 2015 , т. 37 , № 2 , сс. 209-220

Оттиски доступны непосредственно от издателя

им. Г. В. Курдюмова НАН Украины)

Фотокопирование разрешено только

Напечатано в Украине.

в соответствии с лицензией

PACS numbers: 61.66.Dk, 61.72.Qq, 61.72.up, 62.20.fk, 62.20.Qp, 81.30.Fb, 81.70.Jb

\title{
The Influence of Higher Silicon Content on the Hardness of Spheroidal Graphite Cast Iron
}

\author{
Iva Nová and Jiř́i Machuta
}

Technical University of Liberec,

Studentská, $1402 / 2$,

46117 Liberec 1, Czech Republic

This article is concerned with the production of cast iron with spheroidal graphite (ductile iron) for the automotive industry. The properties of materials for automotive parts must be favourable, primarily for reasons of safety for the occupants of the vehicle. Therefore, the materials must be hard but sufficiently malleable, so that they can be significantly deformed upon impact without breaking. These favourable properties characterise ductile iron with high silicon content. As far as producing this cast iron is concerned, the metallurgical preparation of the alloy must be carefully carried out, and suitable charge materials must be selected, including modification and inoculation. The quality of the prepared alloy significantly affects the solidification process in both thin and thick parts of the castings. The aim of our research described in this article is to find the appropriate type and quantity of raw materials, modifiers and inoculants, and the required quantity of silicon in order to ensure the homogeneity of hardness in various casting thicknesses.

Цю статтю присвячено проблемі виробництва ливарного чавуну з кулеподібним графітом (ковкий чавун) для автомобільної промисловости. Властивості матеріялу для автомобільних деталів мають, в першу чергу, забезпечити безпеку пасажирів транспортного засобу. Тому ці матеріяли мають бути твердими, але достатньо пластичними, щоб вони могли значною мірою деформуватися при ударі без руйнування. Такі цінні властивості має ковкий чавун з високим вмістом кремнію. Що стосується виробництва цього ковкого чавуну, то має бути виконана ретельна металургійна підготовка стопу, включаючи модифікацію та інокуляцію, та відібрані відповідні шихтові матеріали. Якість підготовленого стопу істотно впливає на процес твердіння як тонких, так і товстих частин виливок. Метою нашого дослідження, описаного в даній статті, є визначення придатного типу та кількости сировини і модифікаторів, а також кількости кремнію, потрібної для забезпечення однорідности величини твердости при різних товщинах виливок. 
Данная статья посвящена проблеме производства литейного чугуна с шаровидным графитом (ковкий чугун) для автомобильной промышленности. Свойства материала для автомобильных деталей должны, в первую очередь, обеспечивать безопасность пассажиров транспортного средства. Поэтому эти материалы должны быть твёрдыми, но достаточно пластичными, чтобы они могли значительно деформироваться при ударе без разрушения. Такими ценными свойствами характеризуется ковкий чугун с высоким содержанием кремния. Что касается производства этого ковкого чугуна, то должна быть проведена тщательная металлургическая подготовка сплава, включая модификацию и инокуляцию, и отобраны подходящие шихтовые материалы. Качество подготовленного сплава существенно влияет на процесс затвердевания как тонких, так и толстых частей отливок. Целью нашего исследования, описанного в данной статье, является определение подходящего типа и количества сырья и модификаторов, а также количества кремния, необходимого для обеспечения однородности величины твёрдости при различных толщинах отливок.

Key words: hardness, modification, inoculation, spheroidal graphite cast iron, silicon.

(Received 13 August, 2014)

\section{INTRODUCTION}

At present, the automotive industry uses materials with a high degree of ductility. This property is important for increasing the safety of the occupants of the vehicle. Materials are used which consume a large quantity of energy upon impact, which deforms them, but they cannot be allowed to be destroyed. This kind of material includes some kinds of cast iron with spheroidal graphite. At the end of the 1990s, Björkegren [1-3] began development of a cast iron with spheroidal graphite for the automotive industry. This ductile iron was to fulfil the need for ductility and also machinability for both thick and thin parts. This can be ensured by the presence of a silicon content of $3.2 \%$ to $3.7 \%$. The results of his research have been incorporated into ISO 1083:2004 (E). This ductile iron has strength of $500 \mathrm{MPa}$, a hardness of 185-215 HB and minimum ductility of $10 \%$, for castings with a wall thickness of $\leq 30 \mathrm{~mm}$. The limit silicon content is $3.5 \%$ according to CSN EN 15593. The standard CSN EN 1563 summarizes requirements for ductile iron and sets the cast iron mark according to its main required properties. The standard prescribes that the major part of acquired graphite should be of V and VI types, as defined by the standard EN ISO 945:1994. The range of hardness according to CSN EN 1563 should be in the range of $\mathrm{HB} \leq 170$ to 230 .

In this context, systematic research on the production of modified types of cast iron was conducted within the framework of the research 
project 'Support of the creation of excellent research and development teams at the Technical University of Liberec', registration number: No. CZ.1.07/2.3.00/30.0065 in our laboratory at the Department of Engineering Technology, Faculty of Mechanical Engineering, Technical University of Liberec. Metallurgical principles and the production of ductile iron with high silicon content for the automotive industry have already been published [4,9]. This publication introduces the professional public to the mechanical values of this type of cast iron, because it shows that cast iron with high silicon content is a promising foundry material for the automotive industry.

\section{METALLURGY AND PREPARATION OF DUCTILE IRON WITH A HIGH SILICON CONTENT}

Monitoring the properties of ductile iron with high silicon content is a subject to the metallurgical preparation of the alloy [12-14], production of castings and casting of samples. As our laboratory is a wellequipped pilot plant for metallurgical purposes, the metallurgical preparation of the alloy and production of castings and the required samples presents no difficulties. This also contributes to the stability and repeatability of the obtained data, because the casts and measurements are conducted under the same methodological conditions, with the same smelting aggregates and the same measuring equipment, which positively influenced the quality of the experiments conducted. Cleanliness and the homogeneity of the raw materials are important metallurgical conditions. The metallurgical preparation of the alloys is divided into three groups according to the needs of the research [5, 7]:

i) casts of modified magnesium ferroalloys with guaranteed increased silicon content;

ii) casts for the optimisation of the quantity of the inoculant used;

iii) cast for verification of knowledge acquired upon real castings.

The INDUKCE 140 electric medium frequency induction crucible furnace (see Fig. 1, $a$ ) with a crucible capacity of $40 \mathrm{~kg}$ of liquid metal and an acid lining is used for casting. The metal charge consists of ingots of Sorel pig iron and return waste from conventional ductile iron. The silicon content in the charge is supplemented by adding of FeSi75. After the alloy is smelted and heated to approximately $1500^{\circ} \mathrm{C}$, the slag is removed and the alloy is poured into a preheated modification basin. The alloy is modified using the so-called pouring method. The types of modifying agent are used according to the experiment objectives mentioned above. The first dose of inoculant FeSi75 is inserted onto the bottom of the basin, which had been preheated to approximately $600^{\circ} \mathrm{C}$, then the modifier is poured on top and everything is covered in cast iron filings. After pouring the alloy into the pan, a second dose of Superseed inoculant is added; then, the alloy is poured into the pre- 


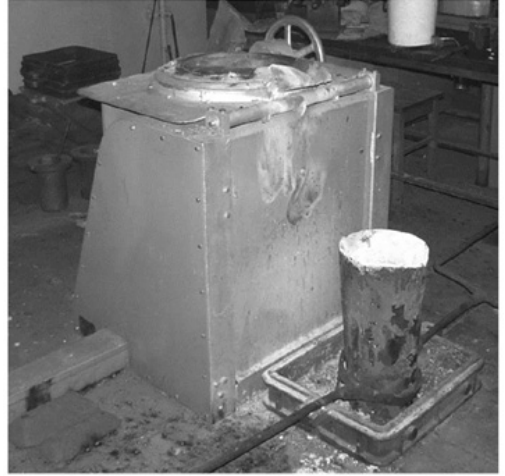

$a$

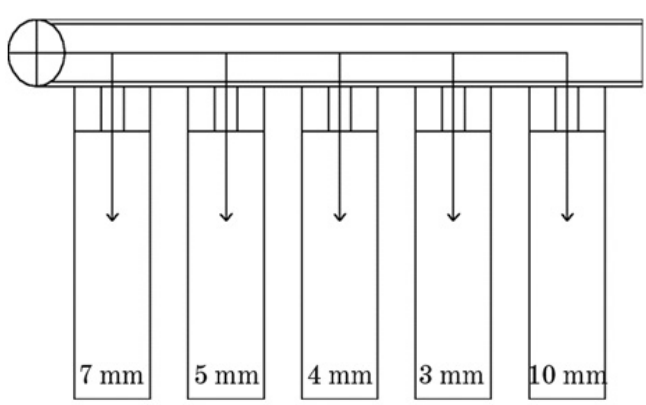

$c$

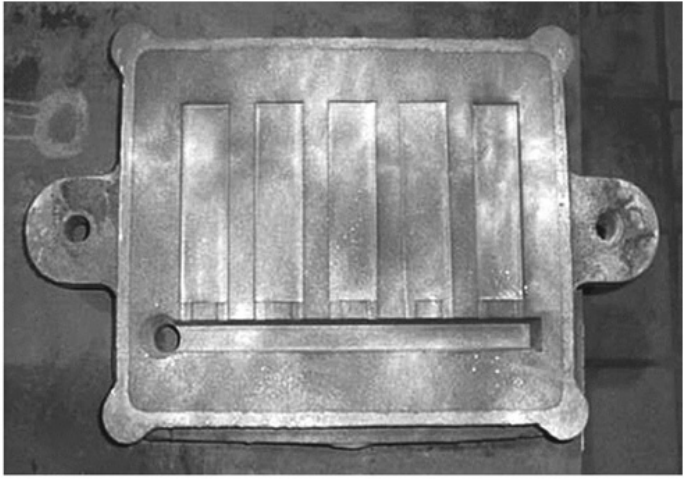

$b$

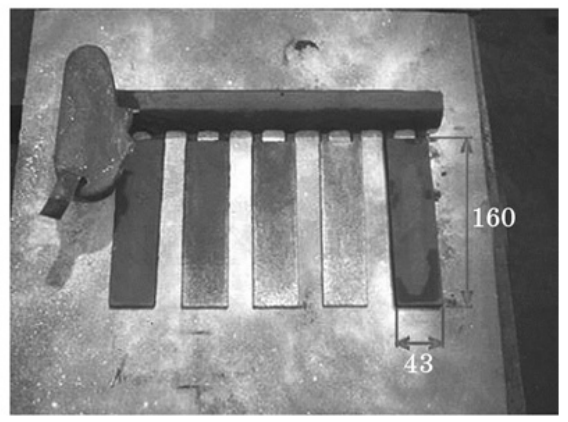

$d$

Fig. 1. Smelting equipment, concrete mould, shape of plate: induction medium frequency furnace $(a)$, inside of the casting mould $(b)$, diagram of system of plate-shaped castings $(c)$, castings $(d)$.

pared casting moulds at a temperature of approximately $1400^{\circ} \mathrm{C}$ [8]. These moulds shown in Fig. $1, b$ are made of a concrete mixture. The castings from these moulds make up a system of plates of $160 \times 43 \mathrm{~mm}^{2}$, with a thickness of $3,4,5,7$ and $10 \mathrm{~mm}$ (see diagram in Fig. 1, c). The system of castings/plates can be seen in Fig. 1, $d$.

Foundry pig iron with the trade name Sorelmetal RTF 10 is used for the basic charge material. This pig iron has very low sulphur, phosphorus and trace element content. Return material (gating and risers) from conventional production of ferrite ductile iron at the Turnov Commercial Foundry of Grey and Nodular Cast Iron is used as an additional metal charge component. Gating residues from our own casts are added in later casts. The chemical composition of these returns will be shown later in an attached table of the chemical compositions of selected casts. The silicon content of each cast is supplemented using the conventional FeSi75 ferroalloy Graphite inoculation is conducted us- 
ing the inoculants FeSi75 and Superseed 75. Rare earth metals and Cer-Mischmetall (C-MM) ferroalloy are used as modifying agents. This ferroalloy is replaced with a magnesium ferroalloy with the trade name of LAMET 5504.

\subsection{Experimental Cast Modified by Magnesium Ferroalloy (LAMET 5504)}

As the modifier based on separated rare earth metals (REM) exhibits a strong carbide effect, it cannot be used for preparing ductile iron with high silicon content. Therefore, the main aim of the experiments conducted is to verify the possibility of using a modifier based on a magnesium ferroalloy with a magnesium content of approximately $5.5 \%$, called LAMET 5504. The charge components are shown in Table 1 . The preparatory method described above is adhered too. The weighed LAMET 5504 modifier is inserted onto the bottom of the pan (preheated to approximately $600^{\circ} \mathrm{C}$ ) and covered with a dose of inoculant and cast iron filings. The plates described above are poured from this cast iron (see also Table 2), and their hardness is measured according to the Brinell method [10]. For this purpose, a hardened steel ball with $\varnothing 5 \mathrm{~mm}$, a load of $7500 \mathrm{~N}$, and measurement of hardness time of 30 seconds are used. Seven hardness measurements are taken for each plate. Mean hardness values for five measurements for each type of plate can be seen in Table 3. The mean hardness value for each thickness of the produced plates (values on the right) is calculated from all measurements. The graphical dependence of the mean hardness values corresponding to the thickness of each plate is plotted in Fig. 2. Differences in hardness between the plates are just $17 \%$, which is favourable. As anticipated, the thinnest plates are the hardest.

TABLE 1. Composition of casts, quantity of modifier and inoculants.

\begin{tabular}{c|c|c|c|c|c|c}
\hline \multirow{3}{*}{ Cast } & \multicolumn{6}{|c}{ Charge, $\mathrm{kg}$} \\
\cline { 2 - 7 } & \multirow{2}{*}{ SOREL } & \multirow{2}{*}{ FeSi75 } & \multicolumn{2}{|c}{ Inoculant } & \multicolumn{2}{c}{ Modifier } \\
\cline { 4 - 8 } & & FeSi75 & Superseed & KVZ & MgFeSi \\
\hline I & 25 & 0.13 & 0.23 & 0.18 & 0 & 0.35 \\
\hline
\end{tabular}

TABLE 2. Chemical composition of cast.

\begin{tabular}{c|c|c|c|c|c|c|c|c|c|c|c}
\hline \multirow{2}{*}{ Cast } & \multicolumn{10}{c}{ Chemical composition, \% } \\
\cline { 2 - 12 } & $\mathrm{C}$ & $\mathrm{Mn}$ & $\mathrm{Si}$ & $\mathrm{P}$ & $\mathrm{S}$ & $\mathrm{Cr}$ & $\mathrm{Ni}$ & $\mathrm{Cu}$ & $\mathrm{Ti}$ & $\mathrm{Mg}$ & $\mathrm{Ce}$ \\
\hline $\mathrm{I}$ & 3.15 & 0.02 & 3.57 & 0.02 & 0.01 & 0.01 & 0 & 0.02 & 0.01 & 0.03 & 0 \\
\hline
\end{tabular}


TABLE 3. Values of hardness of plates (modifier based on $\mathrm{MgFeSi}$ ).

\begin{tabular}{c|c|ccccccc|c|c|}
\hline \multirow{2}{*}{$\begin{array}{c}\text { Cast } \\
\text { Plate thickness, } \\
\text { mm }\end{array}$} & \multicolumn{6}{|c|}{ Hardness of HBS } & & \\
\cline { 2 - 9 } & 3 & 219 & 215 & 229 & 219 & 234 & 239 & 234 & 227.00 & 8.60 \\
& 4 & 217 & 202 & 200 & 207 & 239 & 222 & 234 & 217.29 & 14.20 \\
I & 5 & 207 & 205 & 198 & 202 & 222 & 217 & 222 & 210.43 & 9.08 \\
& 7 & 198 & 197 & 198 & 197 & 201 & 204 & 207 & 200.29 & 3.61 \\
& 10 & 195 & 197 & 193 & 194 & 191 & 195 & 197 & 194.57 & 1.99 \\
\hline
\end{tabular}

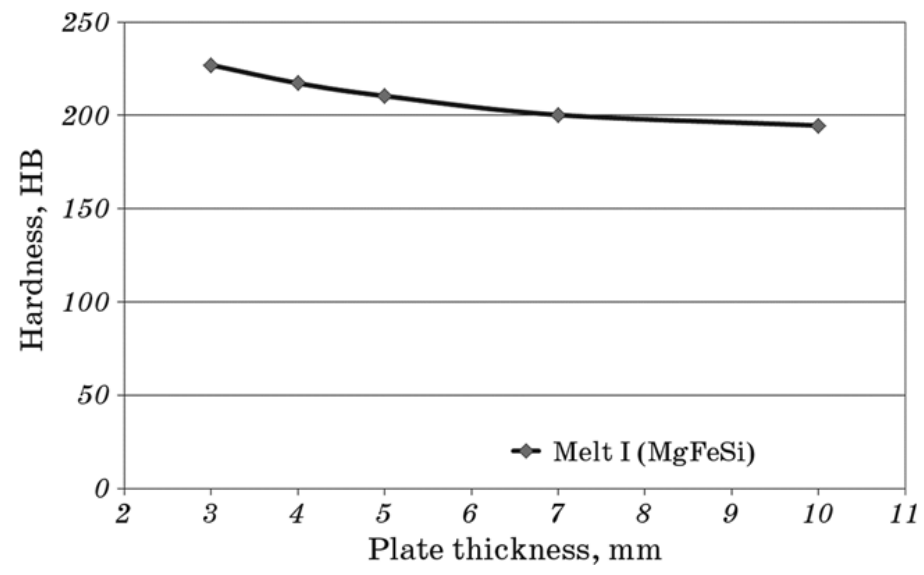

Fig. 2. Hardness of plates using modifier based on MgFeSi.

Meanwhile, the structure of the cast iron produced is observed using Neophot 21 optical microscope. The samples are prepared using a conventional metallurgical process; Nital 3\% is used for corrosion. The structure of the produced cast iron is represented in Fig. 3.

The structure of iron produced from this cast contains regularly spaced graphite, $50 \%$ VI $6+50 \%$ VI 7 . The structure of the basic metal exhibited a maximum of $6 \%$ pearlite.

\subsection{Experimental Casts Made for Effective Inoculation}

The aim of these experiments conducted for the purpose of producing ductile iron with high silicon content is to establish the required amount of inoculant used. As is widely known, alloys for producing thin-walled castings must be thoroughly inoculated. However, using an unnecessarily large quantity of inoculant is ineffective. Several casts are therefore prepared with different inoculant contents so that 
the ratio of inoculant per weight of alloy could be decided on the basis of the acquired microstructures of the cast iron plates produced. The inoculant ratio was between 1 and $2 \%$ in each cast. It is our aim to smelt roughly the same quantity of metal charge in order to maintain the same conditions for inoculation and modification. During our research, we focused on casts with a maximum and minimum amount of inoculant, classified II/ 1 and II/ 2 .

Table 4 shows charge materials for casts II/ 1 and II/ 2 (see also Table 5). Cast II/1 is inoculated with a total of $2 \%$ of inoculant divided into two phases, as was conducted in the previous cast. Cast II/ 2 is inoculated with $1 \%$ of inoculant. Cast II/2 contains more FeSi75 in the

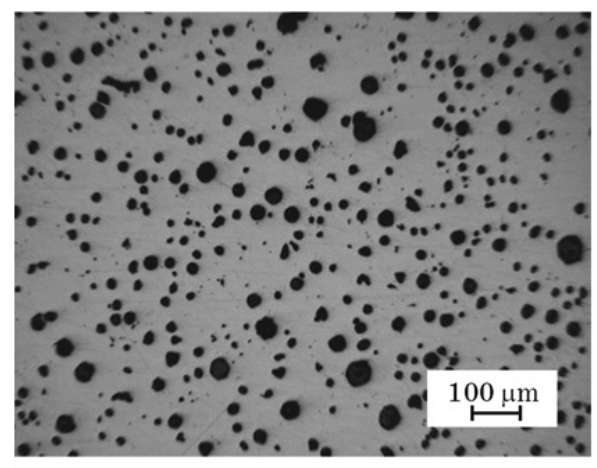

$a$

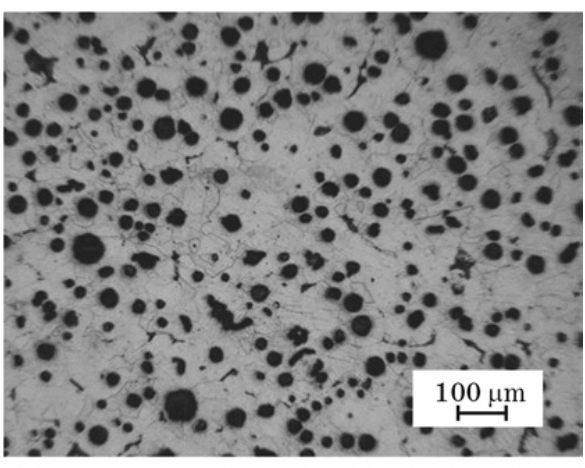

$b$

Fig. 3. Structure of produced ductile iron with modifier MgFeSi: noncorroded (a), corroded (Nital 3\%) (b).

TABLE 4. Composition of cast, quantity of modifier and inoculants.

\begin{tabular}{l|c|c|c|c|c|c}
\hline \multirow{2}{*}{ Cast } & \multicolumn{6}{|c}{ Charge, kg } \\
\cline { 2 - 7 } & \multirow{2}{*}{ SOREL } & \multirow{2}{*}{ FeSi75 } & \multicolumn{2}{|c}{ Inoculant } & \multicolumn{2}{c}{ Modifier } \\
\cline { 4 - 7 } & & & FeSi75 & Superseed & KVZ & MgFeSi \\
\hline II/1 & 15.4 & 0.227 & 0.185 & 0.123 & 0.0022 & 0.219 \\
II/2 & 15.9 & 0.385 & 0.096 & 0.096 & 0.0023 & 0.226 \\
\hline
\end{tabular}

TABLE 5. Chemical composition of cast.

\begin{tabular}{l|c|c|c|c|c|c|c|c|c|c|c}
\hline \multirow{2}{*}{ Cast } & \multicolumn{10}{c}{ Chemical composition, \% } \\
\cline { 2 - 11 } & $\mathrm{C}$ & $\mathrm{Mn}$ & $\mathrm{Si}$ & $\mathrm{P}$ & $\mathrm{S}$ & $\mathrm{Cr}$ & $\mathrm{Ni}$ & $\mathrm{Cu}$ & $\mathrm{Ti}$ & $\mathrm{Mg}$ & $\mathrm{Ce}$ \\
\hline $\mathrm{II} / 1$ & 2.66 & 0.032 & 2.86 & 0.023 & 0.004 & 0.021 & 0.009 & 0.011 & 0.011 & 0.029 & 0 \\
$\mathrm{II} / 2$ & 3.42 & 0.036 & 2.71 & 0.023 & 0.006 & 0.016 & 0.006 & 0.010 & 0.007 & 0.022 & 0 \\
\hline
\end{tabular}


charge to compensate for the silicon which was added in cast II/1 through the greater quantity of inoculant.

The alloys prepared according to these casts were made in moulds for producing castings in the form of a system of plates. The HBS hardness of these plates was measured in the same way as in the previous case. The hardness values are shown in Table 6 and also interpreted in graphical form in Fig. 4.

Comparing the standards according to CSN EN 1563 with the measured values, it is clear that cast II/1 corresponds to quality EN-GJS-

TABLE 6. Values of plate hardness.

\begin{tabular}{|c|c|c|c|c|c|c|c|c|c|c|}
\hline \multirow{2}{*}{ Cast } & \multirow{2}{*}{$\begin{array}{l}\text { Plate thickness, } \\
\mathrm{mm}\end{array}$} & \multicolumn{7}{|c|}{ Hardness of HBS } & \multirow{2}{*}{$x$, HBS } & \multirow{2}{*}{$\sigma, \mathrm{HBS}$} \\
\hline & & \multicolumn{7}{|c|}{ Place of measurement on plate } & & \\
\hline \multirow{5}{*}{$\mathrm{II} / 1$} & 3 & - & - & - & - & - & - & - & - & - \\
\hline & 4 & 170 & 174 & 182 & 175 & 187 & 207 & 193 & 184.00 & 11.95 \\
\hline & 5 & 174 & 175 & 175 & 172 & 174 & 169 & 169 & 172.57 & 2.44 \\
\hline & 7 & 177 & 180 & 160 & 179 & 165 & 172 & 169 & 171.71 & 6.96 \\
\hline & 10 & 169 & 172 & 177 & 170 & 175 & 172 & 172 & 172.43 & 2.56 \\
\hline \multirow{5}{*}{$\mathrm{II} / 2$} & 3 & 160 & 166 & 166 & 165 & 229 & 229 & 230 & 192.14 & 32.26 \\
\hline & 4 & 164 & 174 & 169 & 170 & 207 & 213 & 210 & 186.71 & 20.41 \\
\hline & 5 & 170 & 175 & 169 & 173 & 187 & 202 & 190 & 180.86 & 11.48 \\
\hline & 7 & 169 & 169 & 172 & 170 & 170 & 174 & 172 & 170.86 & 1.73 \\
\hline & 10 & 169 & 172 & 172 & 170 & 172 & 172 & 171 & 171.14 & 1.12 \\
\hline
\end{tabular}



Fig. 4. Hardness of plates using modifier based on $\mathrm{MgFeSi}, 1 \%$ and $2 \%$ inoculant of ductile iron from cast II/ 2 . 


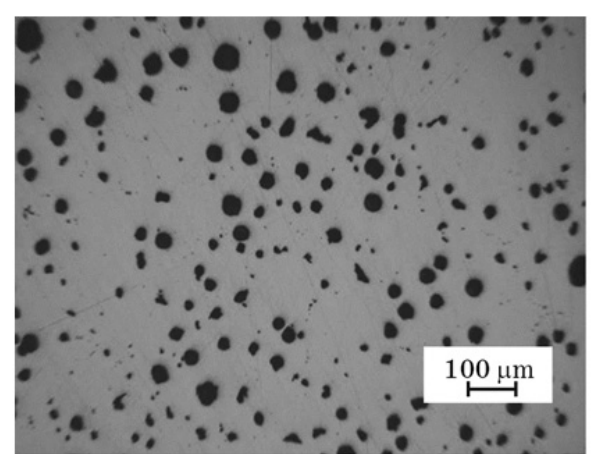

$a$

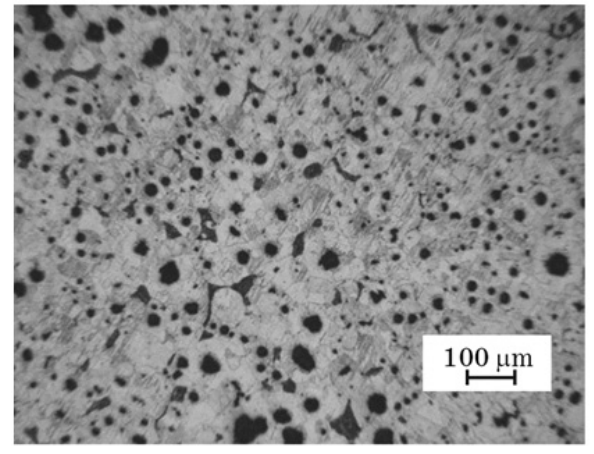

$c$

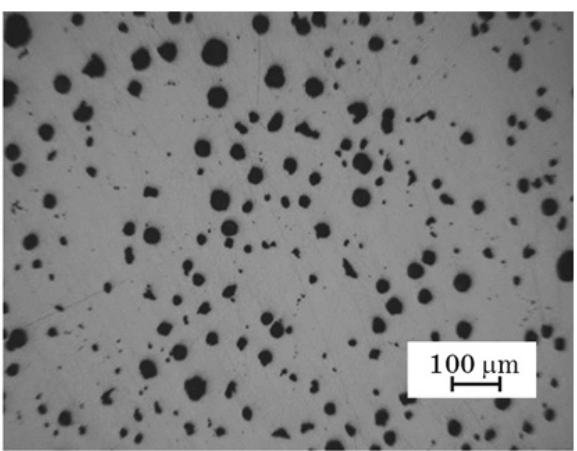

$b$



$d$

Fig.5. Shape of graphite and structure of ductile iron from casts II/1 and II/2: graphite from cast II/1 $(a)$, graphite from cast II/2 $(b)$, structure of ductile iron from cast II/1 $(c)$, structure of ductile iron from cast II/2 $(d)$.

HB185 (EN-GJS-450-10) and cast II/ 2 corresponds to quality EN-GJSHB200 (EN-GJS-500-7). No opacities appeared on the experimental castings. Figure 5 shows the distribution of graphite and structure of the basic metal mass of the cast iron from casts II/1 and II/ 2 .

The cast iron structure shows that graphite is distributed evenly in the plate-shaped castings. For cast II $/ 1,10 \%$ is size 6 and $90 \%$ is size 7. There is a higher count of larger spheres for cast II $/ 2,60 \%$ is size 6 and $40 \%$ in size 7 . The structure is ferrite for plates from cast II/1, while for plates from cast II/1 the structure is ferrite-pearlite $(15 \%$ pearlite).

\section{CASTS FOR PRODUCTION OF INDUSTRIAL CASTINGS}

Based on our long-term findings during the metallurgical preparation of modified cast iron alloys, we proceeded to make castings used in in- 
dustrial practice. In accordance with the experiments conducted, experimental rods and Y-profiles were also produced as well as the poured castings. Table 7 shows the charge used. Table 8 shows the chemical composition of the cast iron produced.

Figure 6 shows castings of a constructive unit (max. $75 \mathrm{~mm}$, max. thickness $15 \mathrm{~mm}$ ) and lever (length $100 \mathrm{~mm}$, thickness $200 \mathrm{~mm}$ ). Figure 7 shows the structures of these castings. Graphite corresponds to the $40 \%$ VI $6+60 \%$ VI 7 mark, the base metal is ferrite. Hardness reached a mean value of $200 \mathrm{HB}$ in parts of the castings with a thickness of $15 \mathrm{~mm}$ and 196 in thicknesses of $20 \mathrm{~mm}$.

Based on all results found during experimental research on ductile iron with high silicon content within the framework of the research projects at our department during last years, the dependence of hardness of cast iron on the amount of silicon for different casting wall thicknesses is plotted (see Fig. 8).

TABLE 7. Composition of casts, quantity of modifier and inoculants.

\begin{tabular}{l|c|c|c|c|c|c|c}
\hline \multirow{2}{*}{ Cast } & \multicolumn{9}{|c}{ Charge, kg } \\
\cline { 5 - 8 } & \multirow{2}{*}{ SOREL } & Foundry & \multirow{2}{*}{$\begin{array}{c}\text { TUL } \\
\text { return } \\
\text { return }\end{array}$} & \multicolumn{2}{|c}{ Inoculant } & \multicolumn{2}{c}{ Modifier } \\
\cline { 5 - 9 } & & FeSi75 & Superseed & KVZ & MgFeSi \\
\hline III & 3.6 & 5.75 & 6.95 & 0.098 & 0.065 & 0.0029 & 0.293 \\
\hline
\end{tabular}

TABLE 8. Chemical composition of cast.

\begin{tabular}{c|c|c|c|c|c|c|c|c|c|c|c}
\hline \multirow{2}{*}{ Cast } & \multicolumn{10}{c}{ Chemical composition, \% } \\
\cline { 2 - 12 } & $\mathrm{C}$ & $\mathrm{Mn}$ & $\mathrm{Si}$ & $\mathrm{P}$ & $\mathrm{S}$ & $\mathrm{Cr}$ & $\mathrm{Ni}$ & $\mathrm{Cu}$ & $\mathrm{Ti}$ & $\mathrm{Mg}$ & $\mathrm{Ce}$ \\
\hline III & 3.31 & 0.131 & 4.15 & 0.025 & 0.009 & 0.023 & 0.015 & 0.058 & 0.009 & 0.035 & 0 \\
\hline
\end{tabular}
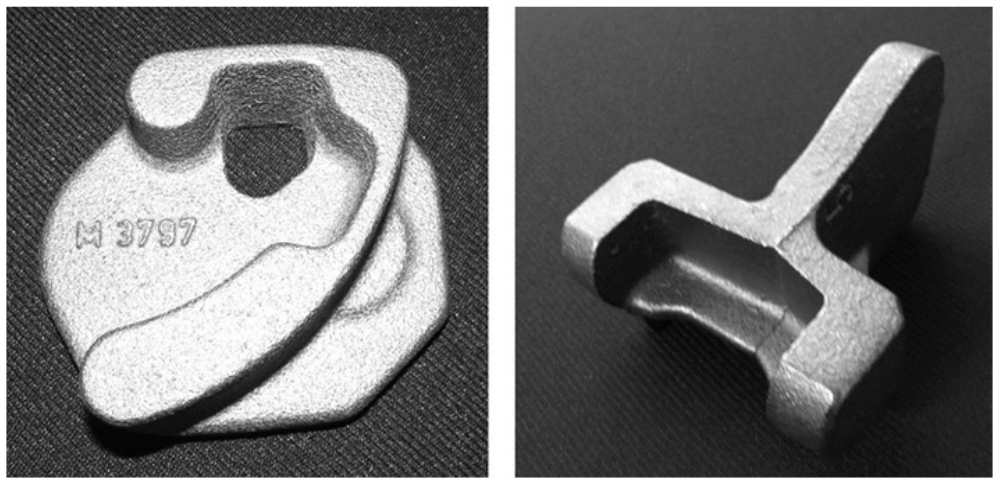

Fig. 6. Castings used in industrial practice. 


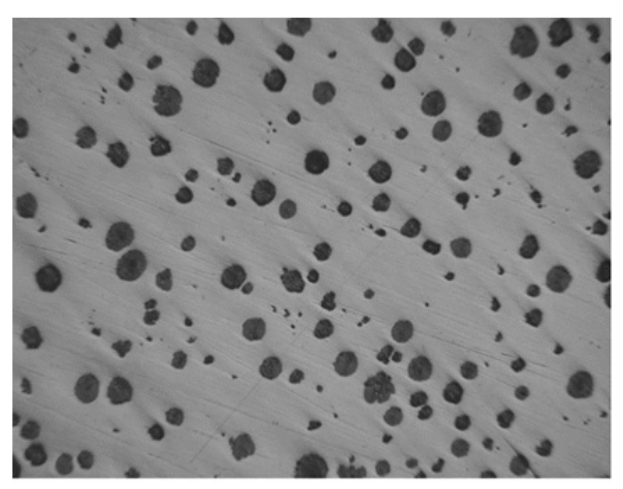

$a$

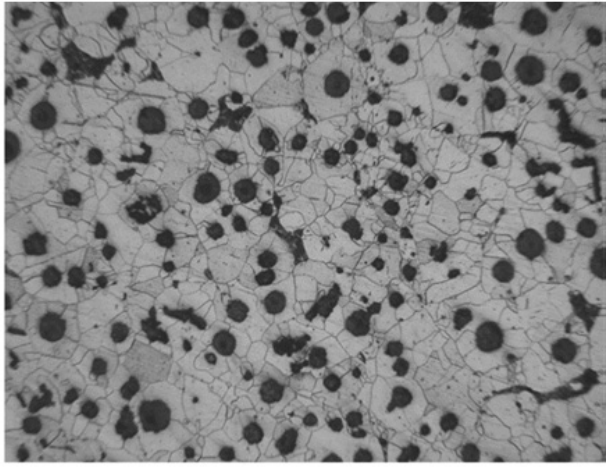

$b$

Fig. 7. Structure of ductile iron castings: shape of graphite (a), structure of ductile iron $(b)$.

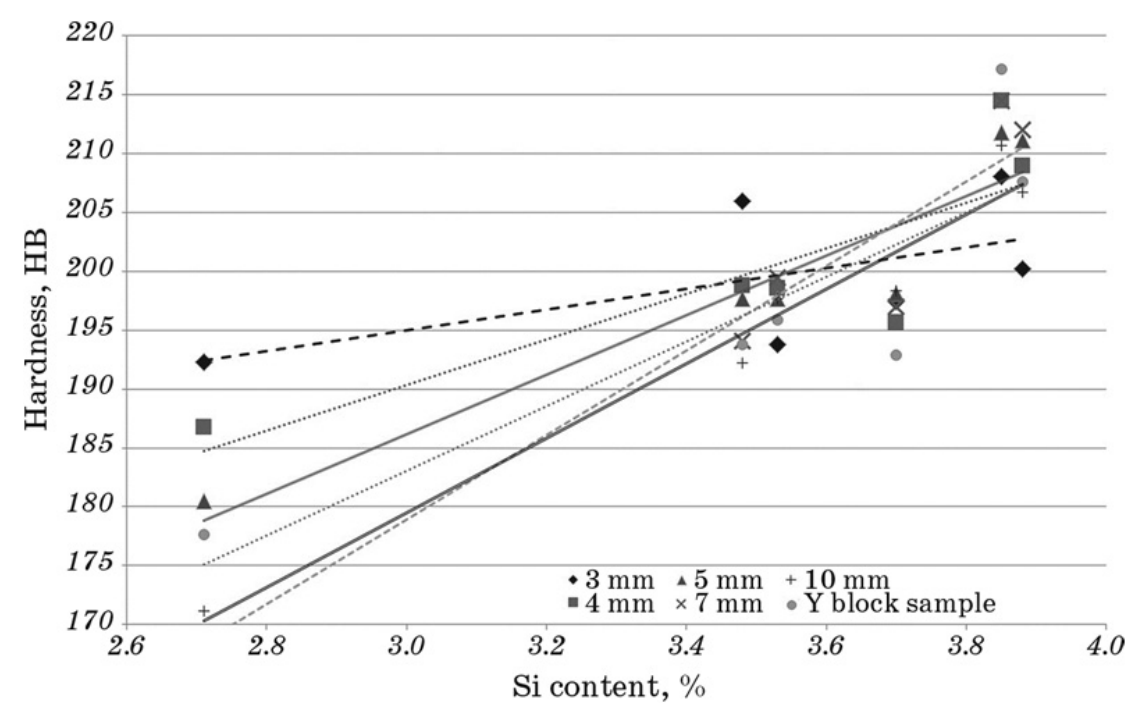

Fig. 8. Dependence of the mean hardness of the casting on silicon in connection with the thickness of the casting wall.

\section{CONCLUSION}

The research conducted on ductile iron confirms that this material does not require any special metallurgical measures from a metallurgical point of view. The only difference from the conventionally produced quality of ductile iron is the charge ratio of the conventional raw materials and their high quality with the carefully considered use of return waste. There is no problem producing this material if these 
principles, which are also valid for conventional ductile iron, and the regulations of the standard ISO 1083, relating to content limits of elements suppressing ferrite base metal, are adhered to. The cast iron produced must contain a maximum of $3.8 \%$ Si for the production of ductile iron with higher silicon content. A medium frequency induction foundry and casting basin (Sandwich) with acid lining is recommended for its production. For a smelting foundry for a weight of $40 \mathrm{~kg}$, we recommend to use $3.6 \mathrm{~kg}$ of SOREL pig iron, $12.7 \mathrm{~kg}$ of return (ductile iron), $0.098 \mathrm{~kg}$ of FeSi75 inoculant and $0.065 \mathrm{~kg}$ of Superseed, $0.003 \mathrm{~kg}$ of REM modifier and $0.029 \mathrm{~kg}$ of FeMn65. Then, it is assumed that castings with a wall thickness from 15 to $20 \mathrm{~mm}$ could achieve a hardness of around $200 \mathrm{HB}$, thereby ensuring their good machinability. This material is highly promising for the automotive industry.

Project was supported by 'Support of the creation of excellent research and development teams at the Technical University of Liberec', registration number: No. CZ.1.07/2.3.00/30.0065.

\section{REFERENCES}

1. L. E. Björkegren, K. Hamburg, and B. Johannesson, AFS Transactions, 104: 139 (1996).

2. L. E. Björkegren and K. Hamburg, Foundry Trade Journal, No. 12: 386 (1998).

3. L. E. Björkegren and K. Hamburg, Proceedings Hommes et Fonderie, 307: 10 (2000).

4. I. Nová, J. Šmrha, I. Nováková, and J. Morávek, Slévárenství, LVII, Nos. 11-12: 391 (2009) (in Czech).

5. J. Šmrha, Vliv Zvýšeného Obsahu Křemíku na MechanickéVlastnosti Tenkostěnných Odlitků z Litiny s Kuličkovým Grafitem (Thesis of Disser. ... for the Degree of Doctor of Science) (Liberec: Technical University of Liberec: 2009) (in Czech).

6. F. Holešovský, Strojírenská Technologie, XI, No. 3: 22 (2006) (in Czech).

7. L. Junek, Výroba Litiny s Kuličkovým Grafitem s Vyšším Obsahem Si pro Automobilový Průmysl (Diplomová Práce) (Liberec: Technical University of Liberec: 2008) (in Czech).

8. J. Minar, Strojírenská Technologie, XIII, No. 2: 13 (2008) (in Czech).

9. I. Nová, I. Novakova, and J. Machuta, Strojírenská Technologie, XVI, No. 5: 18 (2011) (in Czech).

10. M. Ovsik et al., Strojírenská Technologie, XVI, No. 5: 24 (2011) (in Czech).

11. Z. Andršová and B. Skrbek, Manufacturing Technology, 12, No. 1: 93 (2012).

12. Spheroidal Graphite Cast Iron (CSN EN 1563) (1998).

13. I. Nová and J. Machuta, Metallofiz. Noveishie Tekhnol., 36, No. 2: 175 (2014).

14. J. Machuta and I. Nová, Metallofiz. Noveishie Tekhnol., 34, No. 7: 977 (2012). 